\title{
Measurement of Fibrinopeptide A in Human Blood
}

\author{
H. L. Nossei, I. Yudelman, R. E. Canfield, V. P. Butler, JR., \\ K. Spanondis, G. D. Wilner, and G. D. QuRESHI \\ From the Departments of Medicine and Pathology, Columbia University, \\ College of Physicians and Surgeons, New York 10032
}

A B S TRACT Since thrombin cleaves fibrinopeptides $\mathrm{A}$ (FPA) and $\mathrm{B}$ from the $\mathrm{NH}_{2}$-terminal end of the fibrinogen molecule, measurement of fibrinopeptide levels in plasma may provide a direct index of thrombin action. Recently a radioimmunoassay for FPA has been developed, and in the present paper, we describe the application of this assay to the measurement of FPA levels in clinical blood samples. Since fibrinogen cross-reacts with antibodies to FPA, dialysis was used to extract the peptide from plasma. In vitro generation of FPA was prevented by removing the fibrinogen from the plasma by precipitation with ethanol before dialysis. The processing technique permitted recovery of $75 \%$ of FPA added to blood in vitro. Evidence that the immunoreactivity measured in plasma is due to FPA was provided by the results of experiments in which two antisera to FPA with different specificities showed comparable results and addition of thrombin caused no change in immunoreactivity: In contrast, extracts of streptokinasetreated plasma showed a five-fold increase in activity when treated with thrombin and markedly different immunoreactivity with the two antisera.

Plasma FPA levels in 30 normal men were below 2 $\mathrm{ng} / \mathrm{ml}$, with a mean of $0.5 \mathrm{ng} / \mathrm{ml}$. FPA levels in $12 \mathrm{pa}-$ tients with reduced fibrinogen levels or reduced platelet counts or both ranged between 4 and $289 \mathrm{ng} / \mathrm{ml}$. FPA levels in 13 patients with normal or elevated fibrinogen levels, including 6 patients with clinical evidence of venous thrombosis or pulmonary embolism or both, ranged between 5 and $23 \mathrm{ng} / \mathrm{ml}$. FPA and fibrinogen degradation product levels did not correlate, and in several patients, elevated FPA levels were found in the presence of normal fibrinogen degradation product levels. After infusion of FPA-containing solutions in four normal individuals, FPA showed a disappearance rate from the plasma consistent with a ti of 3-5 min. Heparin in-

Dr. Nossel is the recipient of Career Development Award HL 46355. Dr. Wilner is the recipient of Career Development Award HL 70447.

Received for publication 21 November 1973 and in revised form 22 February 1974. fusions in six patients with venous thrombosis or pulmonary embolism or both and elevated FPA levels were followed by a prompt decline in FPA level at a mean rate equivalent to a $3-5 \mathrm{~min} \mathrm{t}_{3}$.

\section{INTRODUCTION}

During the past decade, a number of new tests have been developed to assist in the diagnosis and investigation of the pathophysiology of intravascular coagulation. Some of these tests depend on measurements of residual fibrinogen in serum derived from blood clotted by thrombin in vitro (1). Such tests cannot be specific either for thrombin or for plasmin action in vivo, and may actually reflect the action of either or both of these enzymes (2). Thrombin action on fibrinogen involves limited proteolysis, resulting in the production of fibrin monomer and the fibrinopeptides A and B. A number of attempts have been made to develop tests for thrombin action in vivo based on the detection of fibrin monomer (3-5). In the present study, assay of fibrinopeptide A (FPA $)^{2}$ was used as a technique for studying thrombin action in vivo. Thrombin cleaves arginyl-glycine bonds to release FPA (16 amino acids) from the NHs-terminal segment of the $A \alpha$ chain and fibrinopeptide B (14 amino acids) from the $\mathrm{NH}_{2}$-terminal segment of the $\mathrm{B} \boldsymbol{\beta}$ chain (6). Thrombin-susceptible bonds are not cleaved by plasmin (7), and hence it seemed possible that measurement of the fibrinopeptides might distinguish the action of thrombin from that of plasmin. Teger-Nilsson (8) was able to demonstrate the presence of fibrinopeptides $A$ and $B$ by chemical methods in the blood of dogs infused with sufficient thrombin to render the blood incoagulable. Since thrombin cleaves the A peptide before the $B$ peptide $(6)$, initial efforts have been focused on measuring the $A$ peptide by the radioimmunoassay technique (9). In the present paper, the application of this assay to clinical blood samples is described. The assay technique was modified to improve the sensitivity

${ }^{2}$ Abbreviation used in this paper: FPA, fibrinopeptide A.

The Journal of Clinical Investigation Volume 54 July 1974.43-53 
of the assay, methods for extracting FPA from plasma were developed, and samples of blood were studied from a number of patients with elevated FPA levels. Immunochemical evidence for the specificity of the assay was obtained, and the in vivo clearance rate of FPA determined. The results of these studies are reported below.

\section{METHODS}

Reagents. Native FPA was prepared from fibrinogen (grade L, 95\% clottable, from A. B. Kabi, Stockholm) as described by Blömback, Blömback, Edman, and Hessel (10). Synthetic FPA was synthesized by the solid phase method of Merrifield (11) or obtained from Schwarz/ Mann Div., Becton, Dickinson \& Co., Orangeburg, N. Y. Thrombin was human thrombin purified by Dr. Kent Miller (12) and given to us by Dr. D. Aaronson of the Division of Biological Standards, Bethesda, Md. Streptokinase was streptodornase-streptokinase from Lederle Laboratories, Div. of American Cyanamid Co., Pearl River, N. Y. Plasmin was obtained from A. B. Kabi, Stockholm or from Dr. Alan Johnson at the New York University School of Medicine. Heparin for in vitro use was obtained from Hynson, Westcott \& Dunning, Inc., Baltimore, Md., and for in vivo use from Wyeth Laboratories, Inc., Div. American Home Products Corp., Philadelphia, Pa. Hirudin was obtained from Sigma Chemical Co., St. Louis, Mo., and Trasylol was purchased from FBA Pharmaceuticals, Inc., New York. Ovalbumin was obtained from Schwarz/ Mann, and charcoal (Norit A) was obtained from the Amend Drug and Chemical Co., Irvington, N. Y. Norit PQF from Eastman Organic Chemicals Div., Eastman Kodak Co., Rochester, N. Y., was equally satisfactory.

Preparation of immunogens. Two FPA-albumin conjugates were used in the present study. Native FPA was coupled to human albumin by the carbodiimide method (13) as previously described, and the antiserum derived from a rabbit immunized with this reagent was termed R2 antiserum. Peptides coupled to albumin with carbodiimide are thought to be covalently linked by either the free $\mathrm{NH}_{2}$ or $\mathrm{COOH}$ groups of the peptide molecules. Immunogen containing FPA coupled to albumin by the $\mathrm{NH}_{2}$ terminal end only was prepared by coupling synthetic FPA to bovine serum albumin with glutaraldehyde as follows: $8 \mathrm{mg}$ synthetic FPA was dissolved in $2 \mathrm{mi} 0.1 \mathrm{M}$ phosphate buffer, $\mathrm{pH}$ 7.0. $40 \mathrm{mg}$ bovine serum albumin (batch number 5612 from Nutritional Biochemicals Corporation, Cleveland, Ohio) was dissolved in $2 \mathrm{ml} 0.1 \mathrm{M}$ phosphate buffer, $\mathrm{pH} \mathrm{7.0,}$ and added to the fibrinopeptide solution. $2 \mathrm{ml}$ glutaraldehyde $(0.021 \mathrm{M})$ was added dropwise at room temperature with constant stirring. The sample was dialysed against three changes of 8 liters of $0.15 \mathrm{M}$ saline buffered with barbital at $\mathrm{pH} 7$ and then lyophilized. Immunoassay of the solution indicated the presence of about $10 \mathrm{~mol}$ FPA immunoreactivity coupled per mol of albumin. The immunoassays were made with both the R2 and R33 antisera.

Antisera. The albumin-peptide conjugate was dissolved in $0.1 \mathrm{M}$ saline at a concentration of $2 \mathrm{mg} / \mathrm{ml}$ and thoroughly mixed with an equal volume of complete Freund's adjuvant in a $2-\mathrm{ml}$ glass syringe until it had thickened. White New Zealand rabbits were injected with the mixture on the following schedule: $0.6 \mathrm{ml}$ into the toe pads at $1 \mathrm{wk}$ intervals for a total of three injections, then $0.4 \mathrm{ml}$ intramuscularly in the haunches at intervals of 2 wk. Specific binding of radiolabeled tyrosinated $A$ peptide by the antisera resulted after 3 mo immunization. Antiserum (R55) to fibrinogen was a gift from Dr. C. Merskey, Albert Einstein College of Medicine, New York.

Radioimmunoassay. Tyrosinated peptide used in the present study was prepared by coupling tyrosine to aminoterminal alanine of synthetic A peptide in a $1: 1 \mathrm{M}$ ratio with the use of the ONP ester method (14) as previously described (9). Tyrosinated FPA was radiolabeled with ${ }^{125} \mathrm{I}$ by the chloramine- $T$ method of Hunter and Greenwood (15). The following reagents were added sequentially to a $0.3-\mathrm{ml}$ microflex vial from Kontes Glass Co., Vineland, N. J.: $10 \mu \mathrm{l}$ solution containing $2-5 \mathrm{mCi}{ }^{125} \mathrm{I}$ in $0.05 \mathrm{M}$ $\mathrm{NaOH}$ solution: $30 \mu 10.5 \mathrm{M}$ phosphate buffer, $\mathrm{pH} 7.5$; $10 \mu \mathrm{g}$ FPA in $15 \mu \mathrm{l}$ distilled water, and $15 \mu 1$ chloramine $\mathrm{T}(50 \mu \mathrm{g})$ in $0.5 \mathrm{M}$ phosphate buffer, $\mathrm{pH} 7.5 ; 30 \mathrm{~s}$ later $20 \mu \mathrm{l}$ sodium metabisulfite $(96 \mu \mathrm{g})$ in $0.5 \mathrm{M}$ phosphate buffer, $\mathrm{pH} 7.5,20 \mu 1$ heparinized normal human plasma, and $200 \mu \mathrm{l} 0.5 \mathrm{M}, 7.5$, phosphate buffer were added in rapid succession. The human plasma was added to bind damaged radiolabeled peptide. Rabbit albumin $(20 \mathrm{mg} / \mathrm{ml})$ was an equally satisfactory reagent. These reagents also increased the recovery of radiolabeled peptide. The iodinated peptide was separated on a Sephadex G 10 column as previously described (9). The incorporation of isotope into tyrosinated peptide varied from $10-25 \%$. Up to $80 \%$ of the radioactivity could be bound by the two antisera. The radioimmunoassay technique was modified from that previously described (9) to increase sensitivity. Dilutions were made in $0.10 \mathrm{M} \mathrm{NaCl}$ buffered with $0.05 \mathrm{M}$ Tris at $\mathrm{pH} 8.6$, containing $1 \mathrm{mg} /$ $\mathrm{ml}$ ovalbumin. All ovalbumin-containing solutions were made freshly each week. The assay tubes contained $650 \mu 1$ final volume of the following, in order of addition: $100 \mu \mathrm{l}$ of the appropriate antiserum (1/1,000 usually), with or without hirudin, $0.1 \mathrm{U} / \mathrm{ml}$, and $500 \mu \mathrm{l}$ test sample; after $24 \mathrm{~h}$ of incubation at $4^{\circ} \mathrm{C} 50 \mu 1$ tracer (about $10,000 \mathrm{cpm}$ ). After addition of iodinated tyrosine-FPA, a second incubation of $1 \mathrm{~h}$ was made, and $500 \mu 1$ cold $\left(4^{\circ} \mathrm{C}\right)$ charcoal suspension in Tris-buffered saline was added and mixed on a Vortex mixer (Scientific Industries, Inc., Queens Village, N. Y.). The charcoal $(2.5 \%)$ was suspended in Tris-buffered saline $\mathrm{pH} 8.6$ containing $0.35 \%$ ovalbumin. As soon as possible (within $5 \mathrm{~min}$ ) after adding the charcoal, the charcoal was deposited by centrifugation, and the supernatant fluid was decanted and counted on a Packard gamma counter (model number 3320, Packard Instrument Co., Inc., Downers Grove, III.) for 1 min. A control set of dilutions of FPA was tested every day, and normal and pathological plasma samples were always tested on the same days. All incubations were at $4^{\circ} \mathrm{C}$.

Collection and processing of blood. Polyethylene syringes for blood collection were obtained from Sherwood Medical Industries, Inc., St. Louis, Mo. We have observed artifactually elevated FPA levels in normal blood when the venipuncture was faulty so the blood did not flow freely. Using 18-gauge needles or the two-syringe technique, having the anticoagulant in the syringe, or soaking the venipuncture needle in heparin before sampling the blood did not appear to reduce the FPA concentration of the blood. Careful attention was paid to venipuncture technique; free-flowing blood was collected via 20 -gauge needles into polyethylene syringes, and $9 \mathrm{ml}$ blood was mixed with $1 \mathrm{ml} 0.15 \mathrm{M}$ saline containing 1,000 $\mathrm{U}$ heparin and 1,000 $\mathrm{U}$ Trasylol in a polystyrene tube $(80 \times 125 \mathrm{~mm})$ obtained from Kern Chemical Corp., Los Angeles, Calif. The tube was inverted several times and then immediately centrifuged at $1,500 \mathrm{~g}$ at $4^{\circ} \mathrm{C}$ for $20 \mathrm{~min}$. The plasma was separated and processed in one of three ways. In method A, $2.5 \mathrm{ml}$ anhydrous denatured ethanol, formula L982 (from Matheson. Coleman 
\& Bell, East Rutherford, N. J.) was added to $2.5 \mathrm{ml}$ plasma in a $12-\mathrm{ml}$ conical centrifuge tube in an ice bath. After 30 min incubation, the tube was centrifuged at $1,500 \mathrm{~g}$ at $4^{\circ} \mathrm{C}$ for $20 \mathrm{~min} ; 4 \mathrm{ml}$ of the supernatant fluid was pipetted into a fresh conical centrifuge tube, which was recentrifuged at $1,500 \mathrm{~g}$ at $4^{\circ} \mathrm{C}$ for $20 \mathrm{~min}$ to eliminate any remaining precipitate, and the top $2 \mathrm{ml}$ was pipetted into a segment of dialysis tubing and dialysed for at least $24 \mathrm{~h}$ at $4^{\circ} \mathrm{C}$. The dialysis fluid was exactly $8 \mathrm{ml} 0.10 \mathrm{M} \mathrm{NaCl}$ buffered with $0.05 . \mathrm{M}$ Tris at $\mathrm{pH} 8.6$, containing $1 \mathrm{mg} / \mathrm{ml}$ ovalbumin, and was manually inverted once per hour during the daytime. Mechanical stirring without inversion also produces satisfactory FPA recovery. If the dialysis fluid was mixed once an hour manually or stirred mechanically without inversion, the dialysis rate was equivalent to a $t_{3}$ of about 8-12 h, and reproducible recovery of peptide was obtained. The dialysis rate when the dialysis tube was mechanically inverted was equivalent to a $t_{\frac{1}{2}}(16)$ of $3 \mathrm{~h}$, but frequently no recovery at all of added FPA was found. If ovalbumin was omitted from the buffer solution, FPA added to the plasma was not recovered in the dialysate, because, it was thought, of absorption on the walls of the tube. The variable FPA recovery obtained with mechanical inversion was thought to result from denaturation of ovalbumin at the air-fluid interface and consequent precipitation with loss of the carrier protein from the dialysis fluid. The dialysate contained $\mathrm{A}$ peptide at a concentration one tenth that of the original plasma. Visking dialysis tubing (Union Carbide Corp., New York), $\frac{1}{4}$-in inflated, was used for dialysis. It was rinsed in distilled water before use. Although a single reel of dialysis tubing was used in these experiments, experience with other batches of dialysis tubing has been satisfactory. In method $B$, dialysis only was used, without precipitation with ethanol. In method $C$, the processing of the plasma was varied so that the final extract contained FPA at a concentration equal to that of the original plasma. This technique was used only in the experiments in which the influence of heparin infusion was studied on the FPA level in normal individuals. $8 \mathrm{ml}$ anhydrous ethanol was added to $2 \mathrm{ml}$ plasma in $12-\mathrm{ml}$ conical glass centrifuge tubes. After $30 \mathrm{~min}$ incubation at $4^{\circ} \mathrm{C}$, the tubes were centrifuged at $1,500 \mathrm{~g}$ for $20 \mathrm{~min}$, and the top $5.5 \mathrm{ml}$ from each of duplicate centrifuge tubes was pooled, incubated at $4^{\circ} \mathrm{C}$ for a further $30 \mathrm{~min}$ and then centrifuged at $1,500 \mathrm{~g}$ for $20 \mathrm{~min}$. The top $10 \mathrm{ml}$ was pipetted into a $16 \times 100-\mathrm{mm}$ glass tube, and the ethanol was evaporated by blowing a stream of nitrogen gas over the surface of the samples at $40^{\circ} \mathrm{C}$. The dried extracts were reconstituted with $1.33 \mathrm{ml}$ distilled water and $2.66 \mathrm{ml}$ Tris-buffered saline, $\mathrm{pH}$ 8.6. The ionic strength of the reconstituted solution was $0.15 \mathrm{M}$. Heparin in vitro did not influence the radioimmunoassay technique. When the reproducibility of the assay was tested by doing 10 replicate determinations on a single sample of blood, the coefficient of variation was $25 \%$.

In vitro behavior of FPA immunoreactivity derived from the blood of patients with elevated FPA levels. Antiserum binding of FPA derived from two patients' plasma samples was tested as follows: $2 \mathrm{ml}$ of the patients' plasma was processed by method A. The dialysate was divided into two equal-volume aliquots; $100 \mu \mathrm{l}$ of a $1 / 10$ dilution of R2 serum was added to one, and to the other, $100 \mu \mathrm{l}$ buffered saline was added. $2 \mathrm{ml}$ of each of the two filtrates was then dialyzed for $24 \mathrm{~h}$ against $8 \mathrm{ml}$ Tris-buffered saline, $\mathrm{pH} 8.6$, with $1 \mathrm{mg} / \mathrm{ml}$ ovalbumin. The final dialysates were then assayed for FPA activity. The gel filtration behavior of FPA extracted from a patient's blood was tested as fol- lows : $9 \mathrm{ml}$ plasma from patient $\mathrm{C}$. $\mathrm{N}$. was dialysed against $90 \mathrm{ml} 0.1 \mathrm{M} \mathrm{NH}{ }_{4} \mathrm{HCO}_{3}, \mathrm{pH} 8.5$, with $50 \mu \mathrm{g}$ ovalbumin $/ \mathrm{ml}$. After $24 \mathrm{~h}$ dialysis at $4^{\circ} \mathrm{C}$, the dialysate was lyophilized and reconstituted in $4.5 \mathrm{ml}$ distilled water. A $0.5-\mathrm{ml}$ sample of the reconstituted dialysate containing about $7 \mathrm{ng}$ FPA was then filtered over a Sephadex G 25 column, and the elution pattern of FPA was compared with that obtained when native FPA was filtered over the same column.

FPA generation in vitro. The rate of FPA formation in normal blood after sampling was tested as follows: a stopwatch was started as the blood entered the syringe, and after collection of the entire sample of blood required (24 $36 \mathrm{ml}$ ), the needle was withdrawn from the vein and removed from the syringe. The blood in the syringe was mixed by inversion, and at fixed time intervals, $4.5 \mathrm{ml}$ blood was added to $0.5 \mathrm{ml}$ of a $0.15 \mathrm{M} \mathrm{NaCl}$ solution containing $500 \mathrm{U}$ of heparin and $500 \mathrm{U}$ of Trasylol. The plasma was then processed by method $\mathrm{A}$, and the $\mathrm{A}$ peptide levels were measured.

Streptokinase treatment of plasma. After studies in which the concentration of streptokinase and the incubation period were varied, the following procedure, which resulted in maximal generation of FPA immunoreactivity, was used (this immunoreactivity is thought to result from the reaction of fragments of fibrinogen, which include FPA): $0.25 \mathrm{ml}$ streptokinase $(25,000 \mathrm{U})$ was added to $10 \mathrm{ml}$ citrated (1 ml $4 \%$ trisodium citrate $/ 9 \mathrm{ml}$ blood) plasma. After $60 \mathrm{~min}$ incubation at $37^{\circ} \mathrm{C}, 1 \mathrm{ml}$ Trasylol $(1,000 \mathrm{U})$ was added, and $2 \mathrm{ml}$ plasma was processed by method A and assayed.

Estimation of the clearance rate of FPA from the circulation. The disappearance rate of FPA from the circulating blood was studied after infusion of a solution containing FPA. Sterile preparations of clot supernate containing both fibrinopeptides $\mathrm{A}$ and $\mathrm{B}$ were prepared as follows : $20 \mathrm{ml}$ sterile water was added to a $200 \mathrm{mg}$ sterile mixture of anti-hemophilic factor, fibrinogen, and salt obtained from E. R. Squibb \& Sons, New York. The solution was distributed into three sterile $13 \times 100$ glass tubes with a sterile syringe. $16 \mathrm{U}(0.032 \mu 1)$ of human thrombin were acided to each tube, which was incubated at room temperature for $3 \mathrm{~h}$; then the thrombin was neutralized with $16 \mathrm{U}$ of hirudin, and the mixture then frozen overnight at $-40^{\circ} \mathrm{C}$. The next day the sample was thawed, and the fibrin was deposited by centrifuging at $20,000 \mathrm{rpm}$ for 30 min. The supernatant fluid was filtered through an XM50 Amicon ultrafiltration membrane (Amicon Corp., Lexington, Mass.), and $16 \mathrm{ml}$ of filtrate was obtained. Radioimmunoassay of the filtrate showed a total amount of 1.2 $\mathrm{mg}$ FPA at a concentration of $75 \mu \mathrm{g} / \mathrm{ml}$. The material was prepared with aseptic technique throughout, and sterility testing of the final solution showed no bacterial growth. The solution was stored in $1-\mathrm{ml}$ aliquots at $-40^{\circ}$ until it was used. Samples of the solution containing $150-600 \mu \mathrm{g}$ FPA activity in $2-8 \mathrm{ml}$ saline were injected into the connecting tubing of an intravenous saline infusion (20 gauge needle) in the left arm. A 19-gauge butterfly needle was dipped in a $20,000 \mathrm{U} / \mathrm{ml}$ heparin solution and inserted into $\mathrm{a}$ vein in the right arm. $4.5-\mathrm{ml}$ volumes of blood were withdrawn via the butterfly needle at set intervals. In the intervals between sampling the blood, a saline solution with $2 \mathrm{U}$ heparin/ml was run through the butterfly needle, and about $100 \mathrm{ml}$ of fluid was infused during the $15-\mathrm{min}$ period of sample collection.

Heparin infusions in normal individuals and in patients with thrombosis were made as follows. A 19-gauge butterfly needle was inserted into a superficial arm vein and blood 


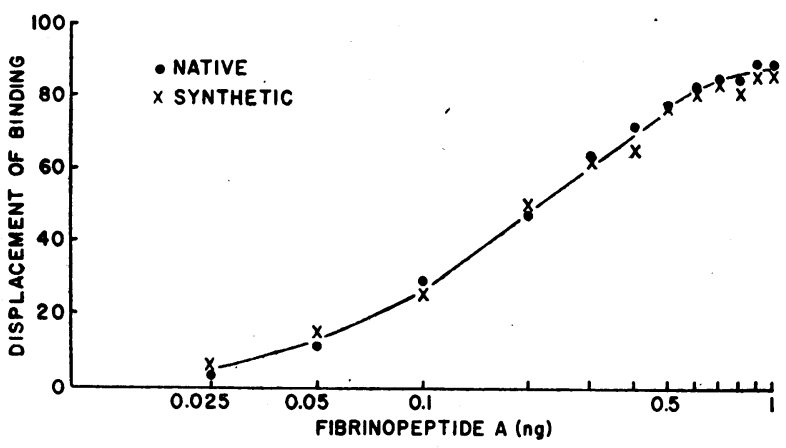

FIGURE 1 Inhibition of binding of ${ }^{120}$ I-labeled tyrosinated peptide $A$ by native and synthetic fibrinopeptide. $500 \mu l$ volumes that contained various concentrations of native FPA (๑) or synthetic FPA (X) were tested. (Amounts shown on abscissa.)

was sampled through the needle before and at intervals after infusion of $10,000 \mathrm{U}$ of heparin.

Previously described methods were used for standard coagulation tests: the partial thromboplastin time and onestage prothrombin time tests were as previously described (17); fibrinogen was measured by the Ellis and Stransky (18) and Ratnoff and Menzie (19) methods. The thrombin time test was as previously described (20), bovine thrombin being used. Serum was prepared and fibrinogen antigen measured by the tanned red cell hemagglutination inhibition test as described by Merskey, Lalezari, and Johnson (1)

\section{RESULTS}

Assay technique. With the radioimmunoassay technique initially described, $0.8 \mathrm{ng}$ FPA could be measured with accuracy (50\% displacement of binding) at a concentration of $8 \mathrm{ng} / \mathrm{ml}$, and a concentration of $2 \mathrm{ng} / \mathrm{ml}$ (20\% displacement of binding) could be detected. In the clinical studies, the radiolabeling technique was improved, preincubation was employed, and a larger volume of test solution tested. These modifications permitted accurate measurement of $0.4 \mathrm{ng} \mathrm{FPA} / \mathrm{ml}$ of solu- tion ( $50 \%$ inhibition of binding), and $0.15 \mathrm{ng} / \mathrm{m}$ l could be detected (Fig. 1). The incubation time and antiserum concentration were adjusted so that between 30 and $40 \%$ of the radiolabeled tyrosinated peptide was bound in the absence of added $A$ peptide.

Processing of blood. Measurements in unextracted plasma were unsatisfactory because fibrinogen crossreacted with the antisera and because variation in the protein concentration of the test solution significantly affected the binding of the tracer when the charcoal was used to separate unbound radioactivity. Extraction by filtration through an XM50 ultrafiltration Amicon membrane gave reproducible results with buffer solutions but variable results were obtained when plasma samples were tested. Dialysis for $24 \mathrm{~h}$ through 1 -in dialysis tubing gave reproducible recovery of $75-100 \%$ of FPA added to plasma (Table I) or to whole blood.

FPA generation in vitro. It was clearly necessary to prevent in vitro generation of FPA activity, and it was found that when different anticoagulant mixtures were added to the blood, the lowest $\mathrm{A}$ peptide levels were obtained with a mixture of heparin, hirudin, and Trasylol or of heparin and Trasylol alone (Table II). Grossly higher immunoreactivity levels were obtained when R33 antiserum was used than when R2 antiserum was used (Table II). To define the meaning of the discrepancy, a series of experiments was made. Synthetic and native FPA and dialysates of thrombin-treated plasma showed equivalent immunoreactivity with both R2 and R33 antisera (Table III). Thrombin treatment did not alter the activity of native or synthetic $A$ peptide. On the other hand, dialysates derived from plasma treated with streptokinase showed a significant increase in reactivity when treated with thrombin (Table III). Dialysates derived from streptokinase-treated plasma also showed significantly higher immunoreactivity when tested with the R33 antiserum than when tested with the R2 antiserum

TABLE I

Recovery of FPA Added to Plasma

\begin{tabular}{cccccc}
\hline & $\begin{array}{c}\text { Plasma not precipitated } \\
\text { with ethanol } \\
\text { Method B }\end{array}$ & & \multicolumn{2}{c}{$\begin{array}{c}\text { Plasma precipitated } \\
\text { with ethanol } \\
\text { Method Ant of }\end{array}$} \\
\cline { 2 - 3 } $\begin{array}{c}\text { FPA added } \\
\text { to 2 ml } \\
\text { plasma }\end{array}$ & $\begin{array}{c}\text { Amount of } \\
\text { FPA } \\
\text { recovered }\end{array}$ & $\begin{array}{c}\text { Percent } \\
\text { recovery }\end{array}$ & & $\begin{array}{c}\text { Amount of } \\
\text { FPA } \\
\text { recovered }\end{array}$ & $\begin{array}{c}\text { Percent } \\
\text { recovery }\end{array}$ \\
\hline$n g$ & $n g$ & $\%$ & & $n g$ & $\%$ \\
10 & 11 & 102 & & 7.6 & 76 \\
20 & 18.8 & 94 & & 15.2 & 76 \\
40 & 38.6 & 96 & & 30 & 75 \\
80 & 68 & 85 & 59 & 74 \\
\hline
\end{tabular}

The FPA level of the plasma was $0.40 \mathrm{ng} / \mathrm{ml}$. The results represent the mean of four separate experiments. 
TABLE II

Plasma FPA Immunoreactivity in Blood Mixed with Different Anticoagulants

\begin{tabular}{|c|c|c|c|c|}
\hline \multirow[b]{2}{*}{ Anticoagulants } & \multicolumn{2}{|c|}{$\begin{array}{l}\text { Method B } \\
\text { Plasma dialysed without } \\
\text { ethanol precipitation }\end{array}$} & \multicolumn{2}{|c|}{$\begin{array}{l}\text { Method A } \\
\text { Plasma supernate dialysed } \\
\text { after ethanol precipitation }\end{array}$} \\
\hline & $\begin{array}{l}\text { Antiserum to } \\
\text { FPA coupled } \\
\text { to albumin } \\
\text { with carbo- } \\
\text { diimide } \\
\text { (R2) }\end{array}$ & $\begin{array}{l}\text { Antiserum to } \\
\text { FPA coupled } \\
\text { to albumin } \\
\text { with glutar- } \\
\text { aldehyde } \\
\text { (R33) }\end{array}$ & $\begin{array}{l}\text { Antiserum to } \\
\text { FPA coupled } \\
\text { to albumin } \\
\text { with carbo- } \\
\text { diimide } \\
\text { (R2) }\end{array}$ & $\begin{array}{l}\text { Antiserum to } \\
\text { FPA coupled } \\
\text { to albumin } \\
\text { with glutar- } \\
\text { aldehyde } \\
\text { (R33) }\end{array}$ \\
\hline & \multicolumn{4}{|c|}{$n g / m l$} \\
\hline Citrate + Trasylol & 3.9 & 120 & 1.4 & 1.6 \\
\hline Oxalate + Trasylol & 11.4 & 139 & 0.7 & 3.0 \\
\hline EDTA + Trasylol & 8.3 & 127 & 1.1 & 1.8 \\
\hline Heparin + Trasylol & 2.5 & 62 & 0.5 & 0.5 \\
\hline \multicolumn{5}{|l|}{ Heparin + hirudin } \\
\hline + Trasylol & 2 & 63 & 0.5 & 0.6 \\
\hline
\end{tabular}

The following amounts of anticoagulants were used in a $1-\mathrm{ml}$ vol $/ 9 \mathrm{ml}$ blood: Trasylol, $1,000 \mathrm{U}$; trisodium citrate, $0.14 \mathrm{mM}$; sodium oxalate, $1.3 \mathrm{mM}$; EDTA, $0.0134 \mathrm{mM}$; hirudin, $5 \mathrm{U}$. The results represent the mean of those derived from five separate experiments and indicate FPA immunoreactivity.

(Table III). On the basis of these results, it was thought that the $A$ peptide alone ( $\mathrm{A} \alpha$ chain $1-16)$ gave similar results with the two antisera but that larger fragments of the fibrinogen molecule, such as would be cleaved by plasmin and which included FPA, gave relatively lower reactivity with $\mathrm{R} 2$ antiserum when thrombin in the antiserum was inhibited with hirudin. To substantiate this hypothesis, a series of fragments of the fibrinogen molecule were tested with the two antisera. These studies showed that the 16-amino acid A peptide gave the same immunoreactivity with the two antisera, whereas A $\alpha$ chain fragment $1-51$, the $\mathrm{NH}_{2}$-terminal disulfide

TABLE III

FPA Immunoreactivity of FPA Preparations and Dialysates of Normal and Streptokinase-Treated Plasma

\begin{tabular}{|c|c|c|c|c|}
\hline \multirow[b]{2}{*}{ Sample tested } & \multicolumn{2}{|c|}{ R2 antiserum } & \multicolumn{2}{|c|}{ R33 antiserum } \\
\hline & $\begin{array}{c}\text { Antiserum } \\
\text { with } \\
\text { hirudin }\end{array}$ & $\begin{array}{l}\text { Dialysate } \\
\text { treated } \\
\text { with } \\
\text { thrombin }\end{array}$ & $\begin{array}{c}\text { Antiserum } \\
\text { with } \\
\text { hirudin }\end{array}$ & $\begin{array}{l}\text { Dialysate } \\
\text { treated } \\
\text { with } \\
\text { thrombin }\end{array}$ \\
\hline & $n g / m l$ & $n g / m l$ & $n g / m l$ & $n g / m l$ \\
\hline Synthetic FPA & 20 & 20 & 20 & 20 \\
\hline Native FPA & 21.7 & 19.8 & 20.8 & 18.8 \\
\hline Thrombin-treated plasma & $25 \times 10^{3}$ & $25 \times 10^{3}$ & $27 \times 10^{3}$ & $25 \times 10^{3}$ \\
\hline Dialysate of normal plasma & 0.6 & 41 & 35 & 37 \\
\hline $\begin{array}{l}\text { Dialysate of normal plasma } \\
\text { precipitated with ethanol }\end{array}$ & 0.5 & 0.6 & 0.4 & 0.6 \\
\hline $\begin{array}{l}\text { Dialysate of plasma treated with } \\
\text { streptokinase }\end{array}$ & 24 & 132 & 52 & 110 \\
\hline $\begin{array}{l}\text { Dialysate of plasma treated with } \\
\text { streptokinase, then precipitated } \\
\text { with ethanol }\end{array}$ & 36 & 190 & 74 & 180 \\
\hline
\end{tabular}

After $24 \mathrm{~h}$ dialysis, the dialysates of normal plasma or of streptokinase-treated plasma were incubated for $1 \mathrm{~h}$ at $37^{\circ} \mathrm{C}$ with or without thrombin, $1 \mathrm{U} / \mathrm{ml}$, and were then tested for FPA immunoreactivity. When hirudin was added to the antiserum, a concentration of $0.1 \mathrm{U} / \mathrm{ml}$ was used. The results are the mean of those derived from five separate experiments. The fibrinogen content of the plasma was $2.8 \mathrm{mg} / \mathrm{ml}$. 
TABLE IV

FPA Immunoreactivity in Dialysates of Normal Plasma Precipitated with Different Concentrations of Ethanol

\begin{tabular}{|c|c|c|c|c|}
\hline \multicolumn{3}{|c|}{ Concentration of ethanol } & \multirow{2}{*}{$\begin{array}{c}\text { FPA } \\
\text { immunoreactivity } \\
\text { (R.33 antiserum) }\end{array}$} & \multirow{2}{*}{$\begin{array}{l}\text { Effect of ethanol } \\
\text { on the binding } \\
\text { of the radio- } \\
\text { active tracer }\end{array}$} \\
\hline Initial & $\begin{array}{l}\text { After } \\
\text { dialysis }\end{array}$ & In assay & & \\
\hline$\%$ & $\%$ & $\%$ & $n g / m l$ & $\%$ binding \\
\hline 0 & 0 & 0 & 7.7 & 47 \\
\hline 10 & 2 & 1.5 & 10.3 & 45 \\
\hline 20 & 4 & 3 & 2.1 & 44 \\
\hline 30 & 6 & 4.6 & 1.3 & 43 \\
\hline 40 & 8 & 6.1 & 0.7 & 42 \\
\hline 50 & 10 & 7.7 & 0.5 & 42 \\
\hline
\end{tabular}

knot, fragment $\mathrm{E}$ produced by plasmin digestion of fibrinogen, and the intact fibrinogen molecule all showed much higher immunoreactivity on a molar basis with the R33 antiserum than with the R2 antiserum. ${ }^{2}$ It was thought that plasmin proteolysis of fibrinogen (23) during the dialysis of normal plasma might be responsible for cleavage of $\mathrm{NH}_{2}$-terminal fragments of the $\mathrm{A} \alpha$ chain containing FPA that gave higher immunoreactivity with the R33 than with the R2 antiserum. Accordingly, the plasma-processing technique was revised to prevent fibrinogen proteolysis during dialysis, and the fibrinogen in the plasma was first precipitated with ethanol and removed by centrifugation. When normal plasma was precipitated with different concentrations of ethanol,

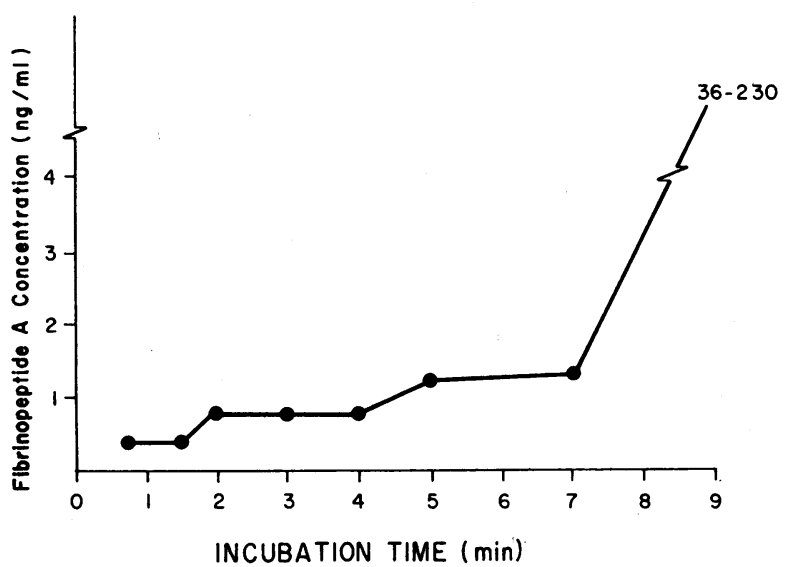

FIGURE 2 FPA levels in normal blood mixed with heparin and Trasylol at various time intervals after sampling the blood. The incubation time represents the time interval between the entrance of blood into the syringe and its mixture with heparin and Trasylol. The results shown are the mean of those obtained in four separate experiments.

${ }^{2}$ Canfield, R. E., J. Dean, H. L. Nossel, and V. P. Butler. 1973. Immunochemical distinction between fibrino peptide $\mathrm{A}$ and larger portions of the fibrinogen molecule containing fibrinopeptide A. In preparation. the supernate of the $50 \%$ ethanol precipitate was found to give the lowest FPA values (Table IV). Such concentrations of ethanol $(7.7 \%$ in the incubation mixture with antiserum) slightly inhibited binding in the assay (Table IV), and an equivalent amount of ethanol was therefore included in the standard fibrinopeptide inhibition curve. Tests of the dialysate of the ethanol precipitate of plasma showed that the high levels of immunoreactivity detected by the R33 antiserum were present in the precipitate. When fibrinogen was first removed from plasma by ethanol precipitation and the plasma then dialysed, similar results with R2 and R33 antisera were obtained with a number of anticoagulant mixtures, and heparin and Trasylol appeared to give similar results to heparin, hirudin, and Trasylol (Table II). Thrombin treatment of the dialysates did not increase the activity, suggesting that fragments of the A $\alpha$ chain larger than the A peptide were not present in significant amounts. Recovery of FPA added to plasma processed by ethanol precipitation and dialysis was about $75 \%$ (Table I). Recovery was similar whether the peptide was added to plasma or to anticoagulated whole blood. For all further studies, the plasma was first precipitated with $50 \%$ ethanol.

In a further experiment, the rate of generation of FPA in normal blood was studied by measuring FPA levels in blood incubated in the collecting syringe for various time periods before mixture with heparin and Trasylol. The FPA concentration remained below 1 $\mathrm{ng} / \mathrm{ml}$ for $3 \mathrm{~min}$ and began to rise steeply only after 7 min (Fig. 2).

Clinical studies. FPA levels in 30 normal men ranged from 0.1 to $2 \mathrm{ng} / \mathrm{ml}$ with a mean of $0.50 \mathrm{ng} / \mathrm{ml}$. Serial FPA estimations in a patient with steady-state defibrination (Kasabach-Merritt syndrome) showed levels ranging from 4.7 to $9.6 \mathrm{ng} / \mathrm{ml}$ with a mean of $6.2 \mathrm{ng} / \mathrm{ml}$. On two occasions, after heparin infusion no FPA was detectable in the patient's plasma (Table V). The pa- 
tient, C. N., is a 20 -yr-old girl with a congenital hemangioma of the right leg extending to the thigh and pelvis.

FPA levels in patients with overt defibrination varied between 4 and $290 \mathrm{ng} / \mathrm{ml}$ (Table VI). FPA levels in several other patients without overt defibrination but with evidence of thrombosis or embolism varied between 5 and $23 \mathrm{ng} / \mathrm{ml}$ (Table VII). Evidence that the immunoreactivity found in the blood of the patients was FPA is provided by the quantitatively similar results obtained when the plasma extract was tested with the R2 and R33 antisera in the presence of hirudin or after thrombin treatment (Tables VI and VII). In patient C. N., a plasma extract was eluted from a Sephadex G 25 column at approximately the same elution volume as FPA (Fig. $3)$. FPA immunoreactivity derived from extracts of two patients' blood was bound in vitro by $R 2$ antiserum and passage through a dialysis membrane was prevented.

FPA clearance in vivo. To interpret the quantitative significance of elevated FPA levels, native fibrinopeptide was infused into four individuals, and the rate of clearance from the circulation was measured. About $70 \%$ of the infused peptide was recovered in the recipients' plasma, and the initial rate of disappearance was equivalent to a $\mathrm{t}_{3}$ of 3-5 min (Fig. 4). After heparin infusion in a number of patients with elevated FPA, the level declined rapidly at a rate equivalent to a $3-5-\min t_{1}$ but usually remained at about $1-2 \mathrm{ng} / \mathrm{ml}$ over the first $15 \mathrm{~min}$ (Fig. $5)$. Heparin infusion in normal individuals resulted in
TABLE V

FPA Immunoreactivity in Plasma of Patient C. N.

\begin{tabular}{clll}
\hline & & \multicolumn{2}{l}{ Concentration } \\
\cline { 3 - 3 } Date & & R2 $\quad$ R33 \\
\hline & & \multicolumn{2}{c}{$n g / m l$} \\
$6 / 8 / 71$ & right arm & 4.8 & 4.6 \\
$11 / 22 / 71$ & right leg & 8.5 & 5.2 \\
& left leg & 6.7 & \\
& & 9.6 & \\
$11 / 23 / 71$ & postheparin & 0 & \\
$11 / 25 / 71$ & & 5.4 \\
$11 / 26 / 71$ & postheparin & 0 \\
& & 4.8 \\
$12 / 10 / 71$ & & 6.1 \\
$12 / 28 / 71$ & & 6.3 \\
$1 / 15 / 72$ & & 4.7 \\
$5 / 4 / 72$ & & 6.1 \\
$6 / 20 / 72$ & & \\
\hline
\end{tabular}

The results of coagulation tests on the patient's blood were as follows: partial thromboplastin time, $88 \mathrm{~s}$ (control $54 \mathrm{~s}$ ); prothrombin time, $32 \mathrm{~s}$ (control $13 \mathrm{~s}$ ); thrombin time, $>180 \mathrm{~s}$ (control $16 \mathrm{~s}$ ); fibrinogen level, 55 (45-65) $\mathrm{mg} 100 \mathrm{ml}$; prothrombin, $58 \%$; factor V, $42 \%$; factor VIII, $24 \%$; factor IX, $58 \%$; factor X, $64 \%$; factor XI, $93 \%$; factor XII, $76 \%$; factor XIII decreased; euglobulin lysis time (with $2 \mathrm{mg} / \mathrm{ml}$ added fibrinogen), $2 \mathrm{~h}$; platelet count $80-120,000 / \mathrm{mm}^{3}$; tanned red cell hemagglutination inhibition assay of nonclottable fibrinogen antigen, $10-20 \mu \mathrm{g} / \mathrm{ml}$ (normal $0-1 \mu \mathrm{g} / \mathrm{ml}$ ). A radiolabeled fibrinogen disappearance study was made in 1964 and showed an accelerated clearance rate (21).

TABLE VI

FPA Levels in the Blood of Patients with Reduced Fibrinogen Levels and/or Reduced Platelet Counts

\begin{tabular}{|c|c|c|c|c|c|c|c|c|}
\hline \multirow[b]{3}{*}{ Patient } & \multirow[b]{3}{*}{ Diagnosis } & \multirow[b]{3}{*}{ Fibrinogen } & \multirow[b]{3}{*}{$\begin{array}{l}\text { Thrombin } \\
\text { clotting } \\
\text { time }\end{array}$} & \multirow[b]{3}{*}{$\begin{array}{l}\text { Fibrinogen } \\
\text { degradation } \\
\text { products }\end{array}$} & \multirow[b]{3}{*}{ Platelets } & \multicolumn{3}{|c|}{ FPA levels } \\
\hline & & & & & & \multicolumn{2}{|c|}{ R2 antiserum } & \multirow[b]{2}{*}{$\begin{array}{c}\mathrm{R} 33 \\
\text { antiserum }\end{array}$} \\
\hline & & & & & & $\begin{array}{l}\text { Antiserum } \\
\text { with } \\
\text { hirudin }\end{array}$ & $\begin{array}{l}\text { Dialysate } \\
\text { treated with } \\
\text { thrombin }\end{array}$ & \\
\hline & & $\mathrm{mg} / 100 \mathrm{ml}$ & $s$ & $\mu g / m l$ & $m l^{-1}$ & & $n g / m l$ & \\
\hline & Normal range & $200-400$ & $14-17$ & $<2$ & $\begin{array}{r}150,000- \\
400,000\end{array}$ & $<2$ & $<2$ & $<2$ \\
\hline P. H. & $\begin{array}{l}\text { Acute immunological disorder, } \\
\text { probable drug sensitivity }\end{array}$ & 0 & $>180$ & & 50,000 & 80 & & \\
\hline J. J. & Acute gram-negative sepsis & 50 & $>180$ & 3 & 62,000 & 4 & & \\
\hline Y.S. & Acute sepsis with E. coli & 305 & 19 & 165 & 125,000 & 41 & 41 & 52 \\
\hline S. B. & Dissecting aneurysm & 140 & 23 & 5 & 32,000 & 17 & & 16 \\
\hline c. T. & Acute myeloid leukemia & 70 & $>120$ & 12 & 19,000 & 11.5 & & 11.7 \\
\hline C. H. & $\begin{array}{l}\text { Lung carcinoma with } \\
\text { metastases }\end{array}$ & 50 & $>180$ & & 100,000 & 290 & & 289 \\
\hline P. N. & $\begin{array}{l}\text { Pancreatic carcinoma, femoral } \\
\text { artery thrombosis, myo- } \\
\text { cardial infarction }\end{array}$ & 276 & 26 & 330 & 90,000 & 140 & 135 & 140 \\
\hline P. M. & Cirrhosis & 90 & 44 & 21 & 23,000 & 18.5 & & \\
\hline I. $\mathrm{T}$. & Liver failure & 125 & 37 & 10 & 80,000 & 6.6 & & \\
\hline L. B. & Liver failure & 85 & 24 & 0 & 27,000 & 16.5 & & 15 \\
\hline G. G. & Liver failure & 95 & $>180$ & $\mathbf{0}$ & 70,000 & 21 & 25 & 20 \\
\hline V. B. & Liver failure, lymphosarcoma & 85 & 65 & 20 & 50,000 & 10.8 & & 12.4 \\
\hline
\end{tabular}


TABLE VII

FPA Levels in the Blood of Patients with Normal or Elevated Fibrinogen Levels and Platelet Counts

\begin{tabular}{|c|c|c|c|c|c|c|c|c|}
\hline \multirow[b]{3}{*}{ Patient } & \multirow[b]{3}{*}{ Diagnosis } & \multirow[b]{3}{*}{ Fibrinogen } & \multirow{3}{*}{$\begin{array}{c}\text { Thrombin } \\
\text { clotting } \\
\text { time }\end{array}$} & \multirow[b]{3}{*}{$\begin{array}{c}\text { Fibrinogen } \\
\text { degradation } \\
\text { products }\end{array}$} & \multirow[b]{3}{*}{ Platelets } & \multicolumn{3}{|c|}{ FPA levels } \\
\hline & & & & & & \multicolumn{2}{|c|}{ R2 antiserum } & \multirow[b]{2}{*}{$\begin{array}{c}\mathbf{R 3 3} \\
\text { antiserum }\end{array}$} \\
\hline & & & & & & $\begin{array}{l}\text { Antiserum } \\
\text { with } \\
\text { hirudin }\end{array}$ & $\begin{array}{l}\text { Dialysate } \\
\text { treated with } \\
\text { thrombin }\end{array}$ & \\
\hline & & $\mathrm{mg} / 100 \mathrm{ml}$ & $s$ & $\mu g / m l$ & $m l^{-1}$ & & $n g / m l$ & \\
\hline & Normal range & $200-400$ & $14-17$ & $<2$ & $\begin{array}{r}150,000- \\
400,000\end{array}$ & $<2$ & $<2$ & $<2$ \\
\hline G. A. & Aortic aneurysm & 320 & 13.7 & 82 & 228,000 & 12.4 & & 10.8 \\
\hline M. B. & Renal transplant rejection & 340 & 14.1 & 0 & 190,000 & 21.3 & & 25.0 \\
\hline E. C. & Renal transplant & 590 & 11.7 & 10 & 150,000 & 12.4 & & 8.4 \\
\hline I. $\mathrm{M}$. & Pulmonary embolism & 280 & 17.7 & & 230,000 & 19.4 & & 15 \\
\hline M. F. & Pulmonary embolism & 330 & 12.2 & 1.3 & adequate & 6.0 & & 5 \\
\hline C. F. & $\begin{array}{l}\text { Venous thrombosis and } \\
\text { pulmonary embolism }\end{array}$ & 640 & 10.3 & 10 & 275,000 & 23 & 31 & 19.8 \\
\hline A. A. & Venous thrombosis & 970 & 14.3 & 10 & 375,000 & 11 & & 9.2 \\
\hline F. T. & Venous thrombosis & 285 & 15 & 10 & & 6.8 & & 9.4 \\
\hline E. $O$. & Venous thrombosis & 610 & 17 & 5 & 340,000 & 10 & 10.2 & 9.4 \\
\hline M. F. & Myocardial infarction & 390 & 18.7 & 2.6 & & 10.3 & & 10.6 \\
\hline N. R. & $\begin{array}{l}\text { Severe arteriosclerotic } \\
\text { vascular disease }\end{array}$ & 520 & 18.5 & 0 & 350,000 & 5.6 & 7.2 & 6.2 \\
\hline IG. N. & $\begin{array}{l}\text { Probable thrombotic } \\
\text { thrombocytopenic purpura }\end{array}$ & 920 & 15.4 & 5.2 & $196,000^{*}$ & 22 & & \\
\hline E. C. & Meningitis & 1,080 & 10.8 & & 200,000 & 15.6 & 13.9 & \\
\hline
\end{tabular}

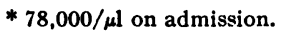

only slight reduction in FPA immunoreactivity measured with the R2 and R33 antisera (Table VIII).

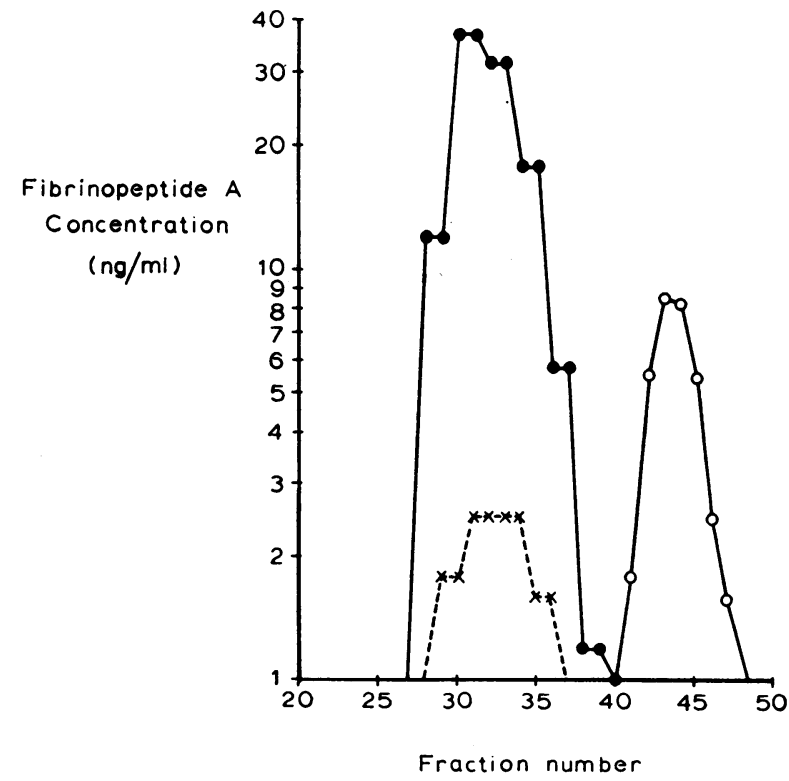

FIGURE 3 The elution from Sephadex G-25 of native FPA and of an extract from C. N. plasma. - native FPA; $\times-\cdots \times$, extract of C. N. plasma ; $\mathrm{O}-\mathrm{O}, \mathrm{C}^{\mathbf{1 4}}$ labeled glucose marker. The column was $45 \times 1.2 \mathrm{~cm}$ and was equilibrated with $10 \%$ acetic acid in $0.01 \mathrm{M} \mathrm{NaCl}$. $1-\mathrm{ml}$ fractions were collected, lyophilized, and redissolved in half the volume of Tris-buffered saline, $\mathrm{pH} 8.6$, with 1 $\mathrm{mg} / \mathrm{ml}$ ovalbumin and assayed for FPA content.

\section{DISCUSSION}

It is recognized that the plasma-processing technique used in the present study is cumbersome, but of the methods tried, it resulted in the most reproducible results. It is to be anticipated that more efficient methods for processing the plasma will be developed.

In interpreting the results obtained, evidence for the specificity of the FPA assay is derived from the results of a number of different experiments. Perhaps the strongest evidence for specificity is derived from the similar FPA levels found with both the R2 and R33

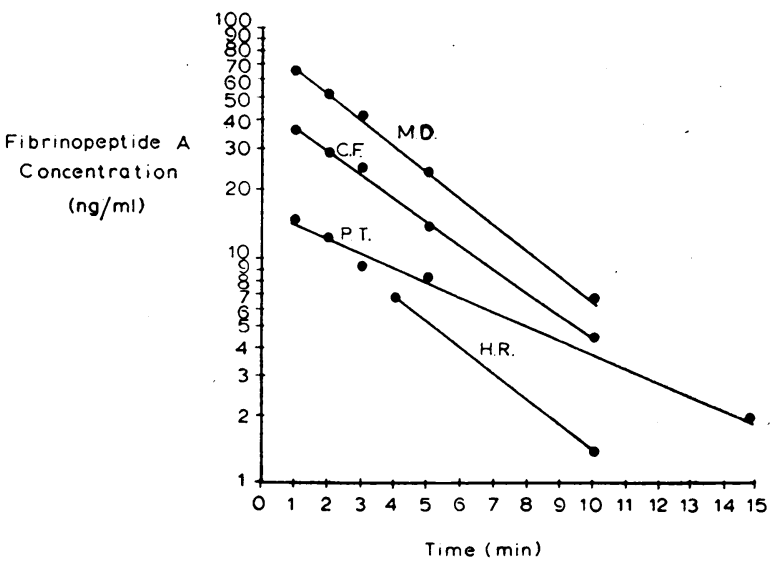

Figure 4 FPA levels in the plasma of four normal subjects infused with fibrin clot supernate containing native FPA. 
antisera (Tables VI and VII). Good evidence has been obtained that these two antisera give similar results with the fibrinogen molecule and fragments of the molecule that include FPA, such as the $\mathrm{NH}_{2}$-terminal disulfide knot and $A \alpha$ chain segment $1-51 .^{2}$ Thus, if significant quantities of $\mathrm{NH}_{2}$-terminal segments of the $\mathrm{A \alpha}$ chain longer than 16 amino acids were present in those samples, one would anticipate greater immunoreactivity with antiserum R33 than with antiserum R2 (Tables II, VI, and VII). Hence, the similar results found in plasma samples studied with these two antisera suggest that most of the immunoreactivity is due to the 16amino acid FPA. The lack of increase in immunoreactivity resulting from thrombin treatment of the dialysates of plasma from which fibrinogen had been removed by precipitation with ethanol before dialysis (Tables III, VI, and VII) strongly suggests that dialysable larger fragments that contain the A peptide are not usually present in plasma samples. It should be noted that the results listed above were obtained with plasma samples precipitated with ethanol within 30 min of collection.

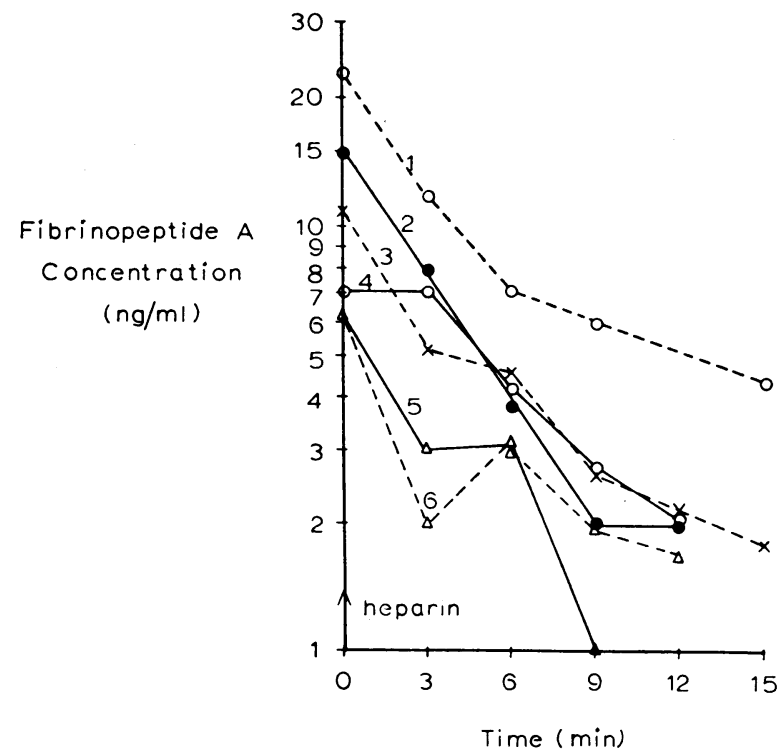

Figure 5 Plasma FPA concentrations in six patients with elevated A peptide levels before and after infusion of heparin.

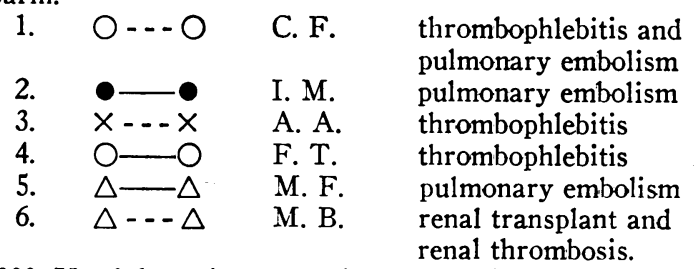

$10,000 \mathrm{U}$ of heparin were given at 0 time as indicated in the figure. The pre-heparin sample was collected $30 \mathrm{~s}$ before infusion of the heparin and the assumption was made that the level had not changed in the $30 \mathrm{~s}$ before the heparin infusion was made.
TABLE VIII

FPA Immunoreactivity in Normal Subjects before and after Infusion of Heparin

\begin{tabular}{lcc}
\hline & \multicolumn{3}{c}{ FPA immunoreactivity } \\
\cline { 2 - 3 } & $\begin{array}{c}\mathbf{R 2} \\
\text { antiserum }\end{array}$ & $\begin{array}{c}\text { R33 } \\
\text { antiserum }\end{array}$ \\
\hline Before heparin & \multicolumn{3}{c}{$n g / m l$} \\
After heparin & 0.69 & 0.33 \\
\hline
\end{tabular}

The blood was processed by method $C$. The results represent the mean of 10 separate experiments. The $P$ value for the difference between the before and after heparin values is $<0.01$. The post-infusion samples were collected $10 \mathrm{~min}$ after infusion of $10,000 \mathrm{U}$ of heparin.

When plasma samples had been stored at $-40^{\circ} \mathrm{C}$ before ethanol precipitation FPA activity increased slightly after thrombin treatment. The almost quantitative recovery of FPA added to plasma suggests that other peptides or dialysable proteins present in normal plasma do not cross-react significantly in the assay (Table I). The similar gel filtration behavior on Sephadex G 25 (Fig. 3) and Biogel P 6 of native A peptide and of the immunoreactivity found in the plasma of patient C. N. is also consistent with the immunoreactivity in this patient's blood being due to FPA.

The prompt decline in elevated FPA levels after heparin infusion is also evidence of specificity. The drop in FPA level is thought to result from cessation of FPA generation in vivo due to neutralization of thrombin by heparin (22).

The dissimilar immunoreactivity levels found in normal plasma with R2 and R33 antisera when the plasma was not precipitated with ethanol is thought to be due to the presence in the dialysates of larger segments of the fibrinogen molecule that include FPA. Evidence for this concept is provided by the findings that the dialysate of streptokinase-treated plasma shows greater reactivity with R33 than with $\mathrm{R} 2$ antiserum and that $\mathrm{A} \alpha$ chain segment 1-51, fragment $\mathrm{E}$, the $\mathrm{NH}_{2}$-terminal disulfide knot, and the complete fibrinogen molecule all show greater reactivity with $\mathrm{R} 33$ than with $\mathrm{R} 2$ antiserum. ${ }^{2}$ The increase in immunoreactivity resulting from thrombin treatment of the dialysate of streptokinase-treated plasma (Table III) is also consistent with the postulated explanation. A possible mechanism for the production of $\mathrm{NH}_{2}$-terminal fragments of the fibrinogen molecule in vitro is via the action of $\alpha_{2}$ macroglobulin bound proteolytic activity (possibly plasmin) (23). Since Harpel and Mosesson (23) showed that the macroglobulin-bound activity was not inhibited by Trasylol, it would be anticipated that proteolytic activity could continue in plasma mixed with heparin and Trasylol. If plasmin is 
responsible, one may consider which fragments of fibrinogen might be responsible for the immunoreactivity found. Two possible cleavage sites are between amino acids 23 and 24 and between 43 and 44 (7). Cleavage of the 1-23 amino acid fragment is suspected because cleavage of the $43-44$ bond would be expected to release a fragment containing beta, gamma, and alpha chains from the $\mathrm{NH}_{2}$-terminal end of the molecule. Such a segment of the fibrinogen molecule would have a molecular weight of about 50,000 and would not be dialysable through the dialysis tubing used here. In contrast, the streptokinase produced immunoreactivity has a dialysis rate indistinguishable from that of FPA. Hence the 1-23 amino acid peptide may be produced by plasmin action and cross-react in the assay. The increase in cross-reactivity of the dialysate from streptokinase-treated plasma on treatment with thrombin ( $\mathrm{Ta}$ ble III) is thought to be due to different conformations of the 1-16 and 1-23 amino acid peptides so that the antigenic determinant of the 1-16 amino acid peptide recognized by the $R 2$ antiserum is partly hidden in the 1-23 amino acid peptide.

It is important to know whether the FPA levels in plasma samples represent circulating FPA or FPA generated in vitro after the venipuncture. The relatively slow rate of FPA generation in blood in vitro (Fig. 2) is against the possibility that thrombin generated as a result of the venipuncture is responsible for the range of FPA levels found in clinical samples. Also indicating that it is circulating FPA which is being measured is the ordered rate of decline in FPA level at a rate equivalent to a $t$ of approximately 3-5 min after heparin infusion in patients with elevated FPA levels (Fig. 5). If the heparin effect were that of preventing thrombin generation in response to the venipuncture, one would expect immediate maximal reduction in the FPA level after heparin infusion.

An important question concerns the significance of the FPA levels found in plasma. Although thrombin action on fibrinogen is the most likely cause of FPA production, other enzymes, such as trypsin, also cleave the bond between amino acids 16 and 17, and the effect should be attributed to thrombin or a thrombin-like enzyme. The results listed in Tables VI and VII indicate a lack of correlation between FPA and fibrinogen-fibrin degradation product levels, and in several patients FPA levels were elevated although the degradation product levels were normal.

Another question concerns the significance of the disappearance rate noted in Fig. 4. It appears that in

\footnotetext{
${ }^{3}$ Note added in proof. When treated with thrombin, $\mathrm{A \alpha}$ chain fragment 1-23 shows a marked (more than fivefold) increase in immunoreactivity measured with $\mathrm{R} 2$ antiserum. (H. L. Nossel and B. Blömback. 1974. Unpublished experiments.)
}

normal subjects the initial clearance rate is consistent with a $\mathrm{t}$ of 3-5 min. The clearance rate may be different in patients with diminished renal function or other disease states. At levels below about $2 \mathrm{ng} / \mathrm{ml}$, it was not clear that the same clearance rate obtains. In patients with thrombophlebitis, heparin infusion was followed by a prompt drop in fibrinopeptide level at a rate consistent with a 3-5-min $t_{1}$. Basing calculations on a 3-5-min $t_{2}$, one may calculate that when the FPA level is $0.5 \mathrm{ng} / \mathrm{ml}$, a production rate is implied of $0.5 \mathrm{ng} / \mathrm{ml} / 3-5 \mathrm{~min}$ or $0.36-0.6 \mathrm{mg} / 24 \mathrm{~h}$ for an individual with a 2.5-liter plasma volume. Such a production rate could be produced by thrombin proteolysis of $40-67 \mathrm{mg}$ of fibrinogen per $24 \mathrm{~h}$, which would represent about $2-3 \%$ of the normal total fibrinogen catabolism of $2.2 \mathrm{~g} / 24 \mathrm{~h}$ in a $70-\mathrm{kg}$ individual (24). These figures are consistent with previously held views that in normal individuals thrombin proteolysis is not a major determinant of fibrinogen catabolism (25). A question that arises about the FPA levels found in normal individuals is whether they represent a state of continuous intravascular thrombin action $(26,27)$. It is not possible to make a definite interpretation of the results, since heparin infusion in normals did not render the A peptide level undetectable. Further work is required to distinguish amongst various possible explanations for the failure of a single heparin infusion to lower the FPA level to an undetectable level. It is possible that the $0.15 \mathrm{ng} / \mathrm{ml}$ difference between the pre- and post-heparin levels is nearer the true normal level than the $0.5 \mathrm{ng} / \mathrm{ml}$ mean normal level found in the 30 normal men tested. Such a level would be produced by proteolysis of 12-20 mg fibrinogen/24 $h$, representing $0.5-1 \%$ of normal total fibrinogen catabolism per day. A $10 \mathrm{ng} / \mathrm{ml}$ FPA level would imply a proteolysis rate of about $0.8-1.3 \mathrm{~g}$ fibrinogen $/ 24 \mathrm{~h}$. All such calculations at present are hypothetical, and their validity must be tested by comparative studies of fibrinopeptide levels and fibrinogen metabolism.

The elevated FPA levels found in patients in whom conventional tests indicate the presence of "defibrination syndrome" or "diffuse intravascular coagulation" were not surprising. The results do not prove the existence of excessive thrombin action in vivo, although that is the favored explanation. The action of other thrombin-like enzymes is not excluded. One of the most provocative results has been the finding of elevated FPA levels in several patients with thrombophlebitis and pulmonary embolism. Further studies will be required to establish the relative frequency and specificity of the elevated FPA levels in relation to pulmonary embolism and venous thrombosis. The possibility that FPA measurements could be used to monitor the influence of physiological circumstances and the therapeutic effectiveness of phar- 
macological agents is one of the most promising arising from the present studies.

\section{ACKNOWLEDGMENTS}

We would like to acknowledge the excellent technical assistance of Michael Drillings and Rita Chatpar.

This work was supported by research grants from the National Institutes of Health (HL 10999, Program Project Grant HL 15486 and SCOR grant HL 14236) and the New York Heart Association.

\section{REFERENCES}

1. Merskey, C., P. Lalezari, and A. J. Johnson. 1969. A rapid, simple, sensitive method for measuring fibrinolytic split products in human serum. Proc. Soc. Exp. Biol. Med. $131: 871-875$.

2. Marder, V. J., M. O. Matchett, and S. Sherry. 1971. Detection of serum fibrinogen and fibrin degradation products. Comparison of six technics using purified products and application in clinical studies. $A m . J$. Med. 51: 71-82.

3. Kisker, C. T., and R. Rush. 1971. Detection of intravascular coagulation. J. Clin. Invest. 50: 2235-2251.

4. Niewiarowski, S., and V. Gurewich. 1971. Laboratory identification of intravascular coagulation: the serial dilution protamine sulfate test for the detection of fibrin monomer and fibrin degradation products. J. Lab. Clin. Med. $77:$ 665-676.

5. Fletcher, A. P., N. Alkjaersig, J. O'Brien, and V. G. Tulevski. 1970. Blood hypercoagulability and thrombosis. Trans. Assoc. Am. Physicians Phila. 83: 159-167.

6. Blömback, B., 1967. Fibrinogen to fibrin transformation. In Blood Clotting Enzymology. Walter H. Seegers, editor. Academic Press, Inc., New York. 143-215.

7. Iwanaga, S., P. Wallen, N. J. Grondahl, A. Henschen, and B. Blömback. 1969. On the primary structure of human fibrinogen. Isolation and characterization of $\mathrm{N}$ terminal fragments from plasmic digests. Eur. J. Biochem. 8: 189-199.

8. Teger-Nilsson, A.-C. 1968. Studies on tissue thromboplastin, thrombin and fibrinopeptides in intravascular coagulation. Acta Physiol. Scand. Suppl. 319: 7-40.

9. Nossel, H. L., L. R. Younger, G. D. Wilner, T. Procupez, R. E. Canfield, and V. P. Butler, Jr. 1971. Radioimmunoassay of human fibrinopeptide A. Proc. Natl. Sci. U. S. A. 68: 2350-2353.

10. Blömback, B., M. Blömback, P. Edman, and B. Hessel. 1966. Human fibrinopeptides. Isolation, characterization and structure. Biochem. Biophys. Acta. 115: 371-396.
11. Merrifield, R. B. 1969 . Solid-phase peptide synthesis. Adv. Enzymol Relat. Arcas Mol. Biol. 32: 221-296.

12. Miller, K. D., and W. M. Copeland. 1965. Human thrombin: isolation and stability. Exp. Mol. Pathol. 4: 431-437.

13. Goodfriend, T., L. Levine, and G. D. Fasman. 1964. Antibodies to bradykinin and angiotensin: a use of carbodiimides in immunology. Science (Wash., D. C.). $144: 1344-1346$.

14. Goodfriend, T. L., and D. L. Ball. 1969. Radioimmunoassay of bradykinin: chemical modification to enable use of radioactive iodine. J. Lab. Clin. Med. 73: 501511.

15. Hunter, W. M. 1967. The preparation of radioiodinated proteins of high activity, their reaction with antibody in vitro: the radioimmunoassay. In Handbook of Experimental Immunology. D. M. Weir, editor. F. A. Davis Co., Philadelphia. 608-654.

16. Craig, L. C. 1967. Techniques for the study of peptides and proteins by dialysis and diffusion. Methods Enzymol. 11 : 870-905.

17. Niemetz, J., and H. L. Nossel. 1969. Activated coagulation factors: in-vivo and in-vitro studies. $\mathrm{Br} . J$. Haematol. 16: 337-351.

18. Ellis, B. C., and A. Stransky. 1961. A quick and accurate method for the determination of fibrinogen in plasma. J. Lab. Clin. Med. 58: 477-488.

19. Ratnoff, O. D., and C. Menzie. 1951. A new method for the determination of fibrinogen in small samples of plasma. J. Lab. Clin. Med. 37: 316-320.

20. Hardisty, R. M., and G. I. C. Ingram. 1965. The thrombin time. In: Bleeding Disorders. F. A. Davis Co., Philadelphia. 285-287.

21. Hillman, R. S., and L. L. Phillips. 1967. Clottingfibrinolysis in a cavernous hemangioma. Am. J. Dis. Child 113: 649-653.

22. Douglas, A. S. 1962. Anticoagulant Therapy. Blackwell Scientific Publications Ltd., Oxford, England. 41.

23. Harpel, P. C., and M. M. Mosesson. 1973. Degradation of human fibrinogen by plasma $\alpha_{2}$-macroglobulin-enzyme complexes. J. Clin. Invest. 52: 2175-2184.

24. Takeda, Y. 1966. Studies of the metabolism and distribution of fibrinogen in healthy men with autologous ${ }^{125}$ I-labeled fibrinogen. J. Clin. Invest. 45: 103-111.

25. Hjort, P. F., and R. Hasselback. 1961. A critical review of the evidence for a continuous hemostasis in vivo. Throm. Diath. Haemorrh. 6: 580-612.

26. Nolf, P. 1908. Contribution a l'étude de la coagulation du sang (5e mémoire). La fibrinolyse. Arch. Int. Physiol. Biochem. 6: 306-359.

27. Astrup, T. 1958. The haemostatic balance. Thromb. Diath. Hacmorrh. 2: 347-357. 